Research Article

\title{
Studies on the antitumor potentials of betulinic acid against murine ascites Dalton's lymphoma
}

\author{
Anamika Bhaumik, Surya Bali Prasad*
}

Department of Zoology, Cell and Tumor Biology Laboratory, North-Eastern Hill University, Shillong-793022, Meghalaya, India

Received: 17 June 2016 Accepted: 08 July 2016

*Correspondence to: Dr. Surya Bali Prasad, Email: sbpnehu@hotmail.com

Copyright: (C) the author(s), publisher and licensee Medip Academy. This is an openaccess article distributed under the terms of the Creative Commons Attribution NonCommercial License, which permits unrestricted noncommercial use, distribution, and reproduction in any medium, provided the original work is properly cited.

\begin{abstract}
Background: Betulinic acid, a naturally occurring pentacyclic triterpene, exhibits a variety of biological activities including anticancer properties. Despite the wide importance of ethnobotanical studies on the anticancer therapeutic uses of betulinic acid, its exact role has not been fully elucidated. Therefore, the present studies were undertaken to evaluate the antitumor effect of betulinic acid in a murine malignant tumor model along with various biochemical changes in the tumor cells of the host.

Methods: Ascites Dalton's lymphoma (DL) tumor-transplanted Swiss albino mice were treated with betulinic acid (i.p., $10 \mathrm{mg} / \mathrm{kg}$ body weight) and the pattern of host's survival was analysed. The viability of DL cells was assessed using trypan blue exclusion test. The DL cells were also studied for the determination of apoptosis using fluorescence microscopy. Reduced glutathione and protein estimations were done in DL cells under different treatment conditions.

Results: Betulinic acid treatment caused a significant increase in life span (ILS $\sim 150 \%$ ) of the tumor-bearing hosts, which may indicate tumor regression/antitumor activity. Following betulinic acid treatment, decrease in DL cells viability and damaging changes in the cell membranes and a decrease in reduced glutathione content in DL cells were observed.

Conclusions: Present findings reveal the potent antitumor activity of betulinic acid against murine ascites Dalton's lymphoma. The cytotoxicity of betulinic acid to build up antitumor effects may involve induction of apoptosis as well as a decrease in glutathione level in tumor cells.
\end{abstract}

Keywords: Betulinic acid, Dalton's lymphoma, Antitumor activity, Apoptosis

\section{INTRODUCTION}

Cancer is one of the most serious health problems to human. According to World Cancer Report released by the World Health Organization (WHO) in 2008, by 2030 it could be expected that there could be 27 million incident cases of cancer worldwide, which is more than double the figures for cancer cases diagnosed in 2008. ${ }^{1}$ Surgery, chemotherapy and radiotherapy are the main conventional methods of cancer treatment. In chemotherapy, hundreds of drugs of diverse chemical nature and implying different mechanisms of action have been used against a wide range of cancers. ${ }^{2,3}$ However, the full use of these drugs has been limited due to development of various side effects in the hosts. Thus, in an attempt to overcome the side effects of chemotherapy, the development of new drugs, using drugs in combination and the use of number of plant as well as animal-derived natural products have been tried. Therefore, natural products have played a major role in the anticancer drug discovery. Over $60 \%$ of the anticancer drugs are obtained from natural sources. Secondary metabolites have wide range of biological properties which can be used for the treatment of various diseases. ${ }^{4}$ Triterpenes represent a varied class of natural compounds. Pentacyclic lupane-type triterpenes possess various medicinal properties. On various in vivo cancer model systems the antitumor properties of lupane-derived triterpenoid plant extracts have been demonstrated..$^{5-9}$

Betulinic acid (3b-hydroxy-lup-20(29)-en-28-oic acid), (Figure 1) is a naturally occurring pentacyclic lupane- 
type triterpene widely distributed in the plant kingdom. ${ }^{10}$ It was originally isolated from the bark of the white birch, Betula pubescens, from which it got its name. ${ }^{11}$ Betulinic acid could also be isolated from various other sources which include ber or Indian plum Ziziphus mauritiana (Rhamnaceae), jamun or jambul, Syzygium formosanum (Myrtaceae), Diospyros spp. (Ebenaceae) and Paeonia spp. (Paeoniaceae). ${ }^{12-20}$ Betulinic acid (BA) exhibits a number of biological properties. However, it is mainly recognized for its anti-HIV-1 activity and specific cytotoxity against a number of tumor cell lines. ${ }^{21}$ The anticancer activity of betulinic acid was initially discovered against human melanoma, and was recognized as "melanoma specific cytotoxic agent. ${ }^{22}$ It has now been shown that betulinic acid exhibits anticancer activity against different types of human cancers like neuroblastoma, leukemia, colon, breast, hepatocellular, lung, prostate, renal cell, ovarian and cervix carcinomas. $^{23-26}$ In anticancer activity, betulinic acid appears to function by means of inducing apoptosis, triggering changes in the mitochondrial membrane potential, production of reactive oxygen species. ${ }^{27}$ Because of its selective cytotoxicity against tumor cells and favourable therapeutic index, and even at doses up to $500 \mathrm{mg} / \mathrm{kg}$ body weight betulinic acid does not demonstrate side effects, thus, suggesting it to be an attractive and promising antitumor agent.

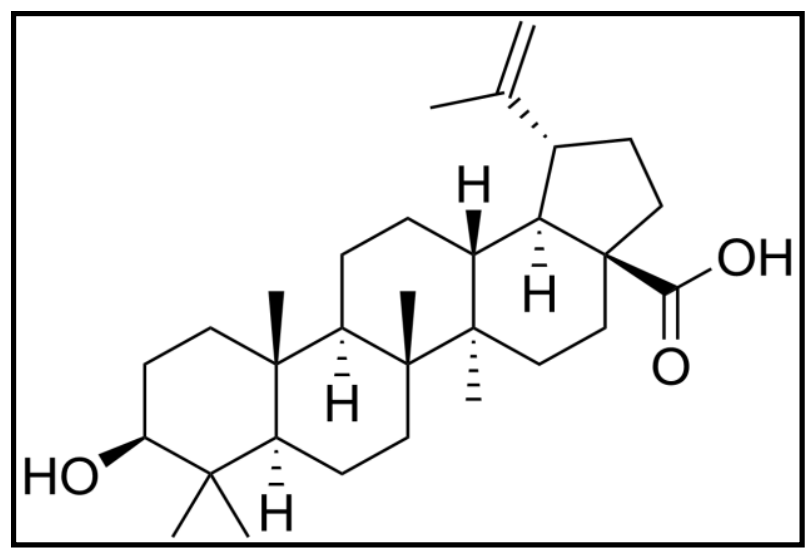

Figure 1: Chemical structure of betulinic acid.

Most of the anticancer research on BA has been carried out using cancer cell lines in vitro and its effect in vivo needs to be further researched. Therefore, on the basis of possible anticancer therapeutic uses of betulinic acid, and as the antitumor activity of betulinic acid has not been assessed in murine ascites Dalton's lymphoma, this study was undertaken to evaluate its anticancer potential in vivo against murine ascites Dalton's lymphoma.

\section{METHODS}

\section{Chemicals}

Betulinic acid ( $\geq 98 \%$ purity), reduced glutathione, and 5,5'-dithiobis-2-nitrobenzoic acid (DTNB) were purchased from the Sigma Chemical Co., St. Louis, Mo, USA. Cisplatin solution ( $1 \mathrm{mg} / \mathrm{ml}$ of $0.9 \% \mathrm{NaCl})$ was obtained from Biochem Pharmaceutical Industries, Mumbai, India. Ethylenediaminetetra-acetic acid (EDTA) and other chemicals used in the experiments were of analytical grade and purchased from SRL Pvt. Ltd., Mumbai, India.

\section{Animals and tumor maintenance}

Inbred Swiss albino mice colony was maintained under conventional laboratory conditions at room temperature $\left(20 \pm 2^{\circ} \mathrm{C}\right)$ with free access to food (Amrut Laboratory, New Delhi) and water ad libitum, keeping 5 to 6 animals in a propylene cage. Ascites Dalton's lymphoma (DL) tumor was maintained in vivo in 10-12 weeks old mice of both sexes by serial intra peritoneal (i.p.) transplantation of viable tumor cells to the animals as per the established procedure in the lab. ${ }^{28}$ Tumor-transplanted hosts usually survived for 19-21 days. Following tumor transplantation, an increase in abdomen size and body weight with sluggish movement of the animals was noted from $3^{\text {rd }}-4^{\text {th }}$ day onwards which was an early sign of tumor development (Figure 2). The maintenance, use of these animals and the experimental protocol of the present study was approved by the institutional ethical committee, North-Eastern Hill University, Shillong.

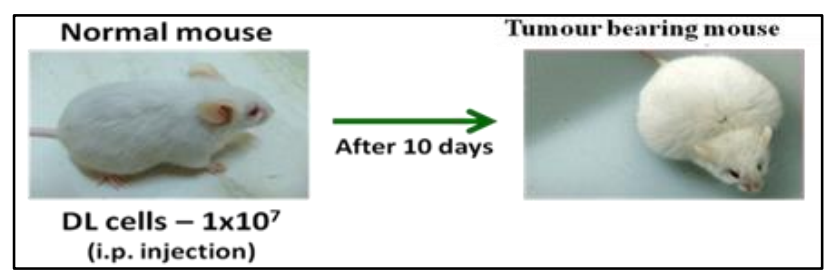

Figure 2: Tumor growth in a normal mouse after transplantation of DL cells.

\section{Drug treatment schedule}

Betulinic acid at a dose of $10 \mathrm{mg} / \mathrm{ml}$ was dissolved in DMSO (dimethyl sulfoxide) before use. It was diluted in PBS (Phosphate buffered saline) to get desired concentration and based on the earlier reports, the therapeutic dose of betulinic acid was selected as 10 $\mathrm{mg} / \mathrm{kg}$ body weight and $0.25 \mathrm{ml}$ of the diluted drug was injected (i.p.) into mice. ${ }^{29}$

The day of tumor transplantation was taken as day ' 0 '. Tumor-transplanted mice were randomly divided into three groups consisting of 10 mice in each group. Group-I mice served as tumor-bearing control and received normal saline only. Group-II mice were injected intraperitonially with betulinic acid $(10 \mathrm{mg} / \mathrm{kg}$ body weight) on the $6^{\text {th }}, 8^{\text {th }}$ and $10^{\text {th }}$ day post-tumor transplantation. Group-III mice were injected intraperitonially with cisplatin $(2 \mathrm{mg} / \mathrm{kg}$ body weight) on the $6^{\text {th }}, 8^{\text {th }}$ and $10^{\text {th }}$ day post-tumor transplantation (Figure 3). 


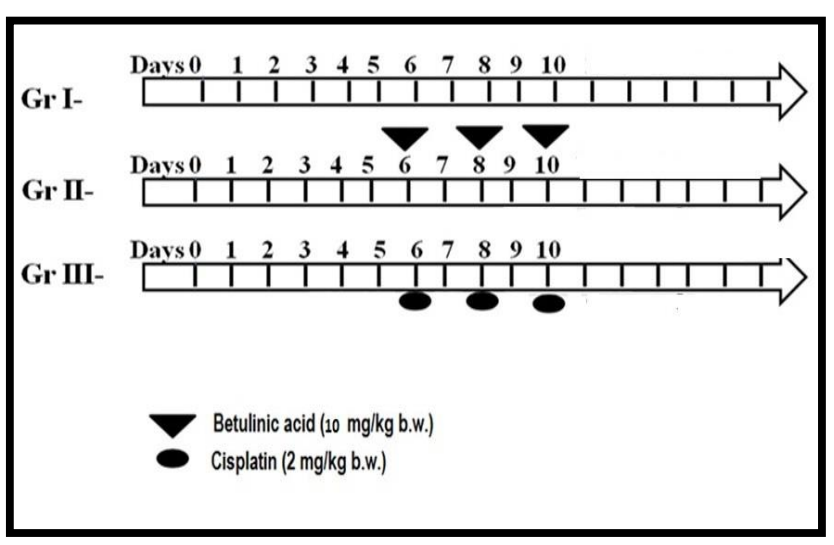

Figure 3: Schedule of drug treatment in tumorbearing mice.

\section{$\%$ ILS $=\frac{\text { Mean survival days for treated animals }}{\text { Mean survival days for control animals }} \quad \times 100-100$}

Similarly for the biochemical analysis, 10 mice were kept in each group and two animals were sacrificed by cervical dislocation after 24, 48, 72 and 96 hours interval following last treatment with the drug (i.e. on the $11^{\text {th }}$, $12^{\text {th }}, 13^{\text {th }}$ and $14^{\text {th }}$ day post tumor transplantation) and the tumor cells were collected separately. The experiments were repeated three times.

\section{Hosts survival and antitumor study}

The survival patterns of animals in each group were monitored daily and deaths, if any, were recorded. The antitumor efficacy was expressed in percentage of average increase in life span (\% ILS), and was calculated using the formula:

(T/C $\times 100$ )-100, where, $\mathrm{T}$ and $\mathrm{C}$ are the mean survival days of treated and control group of mice respectively.

\section{Cell viability}

Viability of DL cells as well as spleen cells (representative of corresponding normal cells) collected under different treatment conditions was checked by trypan blue exclusion test following the method of Talwar. $^{30}$ The DL cells and spleen were collected from mice at different time intervals (24, 48, 72 and 96 hours), washed with PBS and cell suspensions were prepared in PBS. Aliquot of the cell suspension was mixed with an equal volume of trypan blue (0.4\% in PBS) and incubated for 10 minutes. Viable (unstained cells) and dead cells (stained cells) were analysed with a Neubauer haemocytometer under light microscope. The percentage of viability was calculated using the formula:

$\%$ viability = Average total number of viable cells from treated mice/Average total number of viable cells from control mice $\mathrm{x} 100$

\section{Apoptosis study}

Flourescence based apoptosis was determined in DL cells collected from mice under different treatment conditions using acridine orange-ethidium bromide (AO/EB) staining method following the method of Shylesh et al. ${ }^{31}$ as previously used in the lab. After treatment, the DL cells were collected from mice at different time intervals (24, 48, 72 and 96 hours). The cells were washed twice with PBS and treated with AO/EB $(100 \mu \mathrm{g} / \mathrm{ml}$ PBS of each dye) for 5 minutes and gently washed with PBS. The cells in different treatment groups were thoroughly examined under fluorescent microscope and photographed (A1000IS - canon). The viable cells nuclei stain green due to permeability of only acridine orange whereas, apoptotic cells appear red due to co-staining of both the stains. One thousand cells were analysed and percentage of apoptotic cells was counted from twenty selected view fields under microscope.

\section{Scanning electron microscopy}

The DL cells were collected from the animals under varying experimental conditions (as given in the treatment protocol), washed once with PBS and resuspended in PBS. A thin smear of these cells was prepared on a cover glass which was then fixed in $2.5 \%$ (v/v) glutaraldehyde at $4^{\circ} \mathrm{C}$. Fixed cells were rinsed in 0.1 $\mathrm{M}$ phosphate buffer and dehydrated in graded ethanol series of 30, 50, 70, 90 and $100 \%$ for 20 minutes each. Cover glass with cells was then cut in small size and was affixed to an aluminium stub with double stick tape and then critical point-dried in a critical point drier (CPD030, BAL-TEC Co.) and coated with gold in an ionic sputter coater (SCD-005, BAL-TEC Co). They were viewed, examined thoroughly and photographed under the scanning electron microscope (JEOL JSM-6360).

\section{Protein estimation}

The protein estimation in DL cells was determined following the method of Bradford. ${ }^{32}$

\section{Total reduced glutathione (GSH) estimation}

Total reduced glutathione (GSH) level was determined in the DL cells following the method of Sedlak and Lindsay. ${ }^{33}$ Briefly, $5 \%$ tissue homogenates were prepared in $0.02 \mathrm{M}$ EDTA ( $\mathrm{pH} 4.7$ ) in a motor-driven teflon-pestle homogenizer. Total reduced glutathione was determined by adding the homogenate $(0.1 \mathrm{ml})$ to $1 \mathrm{ml}$ of $0.2 \mathrm{M}$ TrisEDTA buffer (pH 8.2) and $0.9 \mathrm{ml}$ of $0.02 \mathrm{M}$ Tris-EDTA buffer ( $\mathrm{pH} 4.7$ ) followed by $20 \mu \mathrm{l}$ of Ellman's reagent (DTNB $0.01 \mathrm{M}$, in methanol). After 30 minutes of incubation at room temperature, the reaction mixture was centrifuged at $3000 \mathrm{xg}$ for 20 minutes and the absorbency of the clear supernatant was read against a reagent blank at $412 \mathrm{~nm}$ in a Carey-100 spectrophotometer. 


\section{Statistical analysis}

The data were expressed as mean \pm SD. Comparisons between the control and treated group were made by oneway ANOVA test (using a statistical package, Origin 6.1, Northampton, MA 01060 USA) with Tukey's multiple comparison tests, $\mathrm{p} \leq 0.05$ was considered as statistically significant in all cases.

\section{RESULTS}

\section{Hosts survivability}

Control tumor bearing mice (group 1) survived for about 19-21 days. The mean survival time of betulinic acidtreated mice were significantly increased to about 50 days with the ILS of about $150 \%$ which was quite comparable with that of cisplatin treatment showing ILS of about $170 \%$ (Figure 4 ).

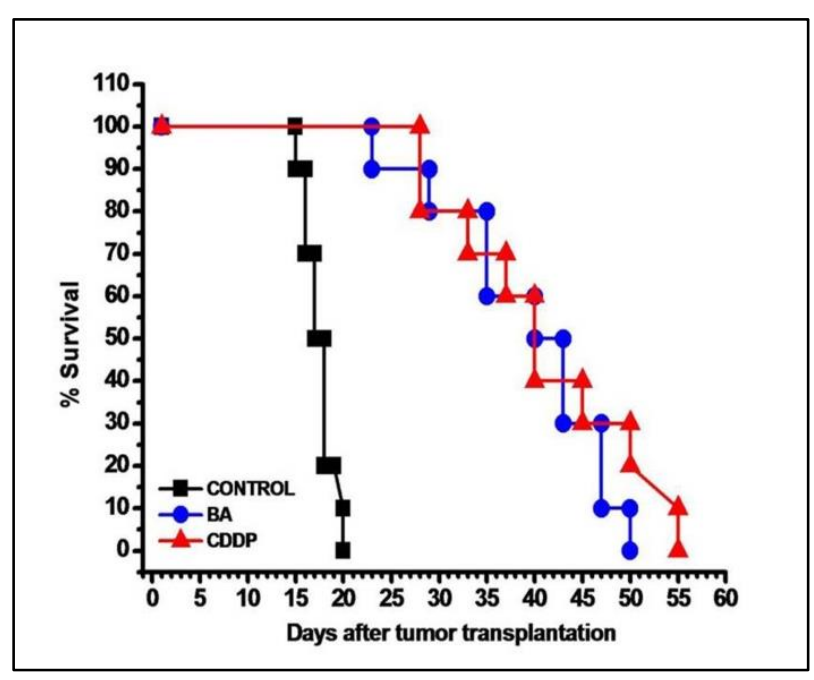

Figure 4: The survival pattern of tumor-bearing mice in control and different treatment groups. BAbetulinic acid; CDDP- cisplatin.

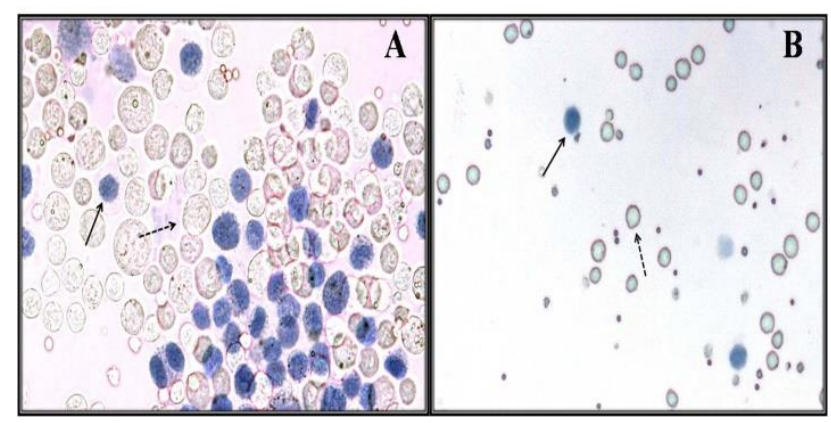

Figure 5: Representative microphotograph to show the cell viability; (A) DL cells after treatment with betulinic acid; (B) Spleen cells after treatment with betulinic acid. Viable cells (dotted arrow) are colourless whereas dead cells (regular arrow) stain blue.

\section{Cell viability}

The viability of DL cells and spleen cells under different treatment conditions in vivo was checked using trypan blue exclusion test (Figure $5 \mathrm{~A}$ and $\mathrm{B}$ ). BA treatment showed a significant decrease in the viability of DL cells in a time dependent manner. However, as compared to DL cells, spleen cells showed much higher viability at the corresponding time of BA treatment. It shows that betulinic acid was more cytotoxic to DL cells as compared to normal cells in the host (Figure 6).

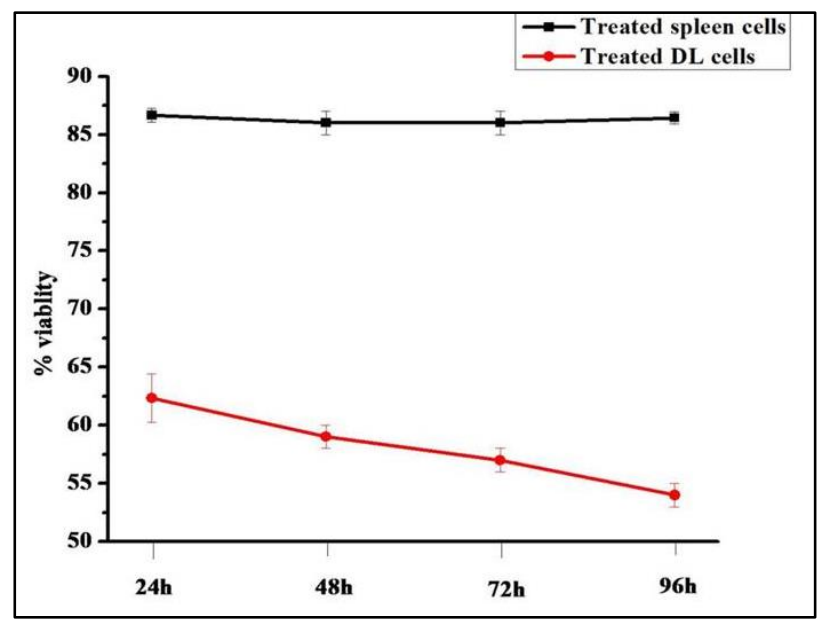

Figure 6: Percent viability of DL cells and spleen cells as determined by trypan blue exclusion test after treatment of tumor-bearing mice with betulinic acid. Results are expressed as mean $\pm \mathrm{SD}, \mathrm{n}=3$.

\section{Apoptosis}
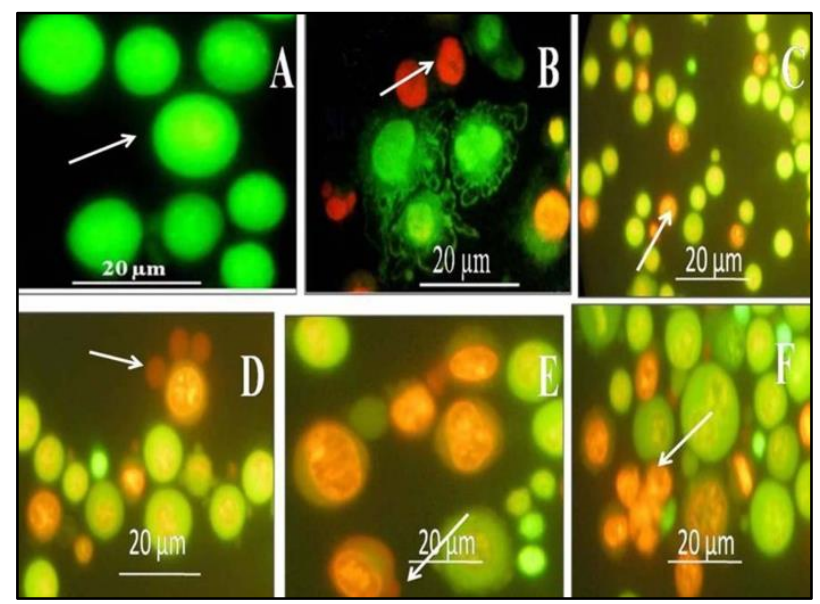

Figure 7: Flourescence based determination of apoptosis in DL cells using AO/EB staining method;

(A) control; (B) cisplatin; (C-F) betulinic acid

treatment for 24-96 hours. Cells stained green represent viable cells, whereas orange/red stained cells represent apoptotic cells.

Acridine orange is a vital dye that stains both live and dead cells, whereas, ethidium bromide stains only those 
cells that have lost membrane integrity. Cells stained green represent viable cells, whereas orange/red stained cells represent apoptotic cells. Control DL cells were round in shape with uniform green fluorescence while cisplatin treatment after 96 hours showed many apoptotic nuclei with membrane blebbing and fragmented nuclei. In betulinic acid treated mice, DL cells illustrated the appearance of membrane blebbing and folding at 24 hours. Chromatin condensation and cell membrane abnormality with fragmented nuclei were observed at 48 hours of BA treatment. After 72 hours of the treatment, cells with severe membrane rupture with many fragmented nuclei and cytoplasmic vacuoles were noted. BA treatment of mice for 96 hours showed the damage in plasma membrane with scattered fragmented nuclei and apoptotic bodies outside the cells. The results suggest that BA was able to induce marked apoptosis in DL cells (Figures 7, 8).

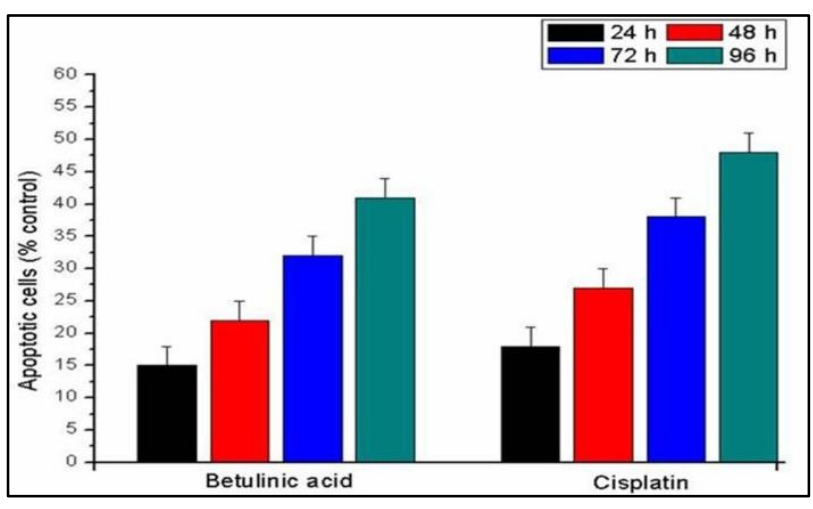

Figure 8: Apoptotic index in DL cells after treatment with betulinic acid and cisplatin respectively.

\section{Scanning electron microscopy}

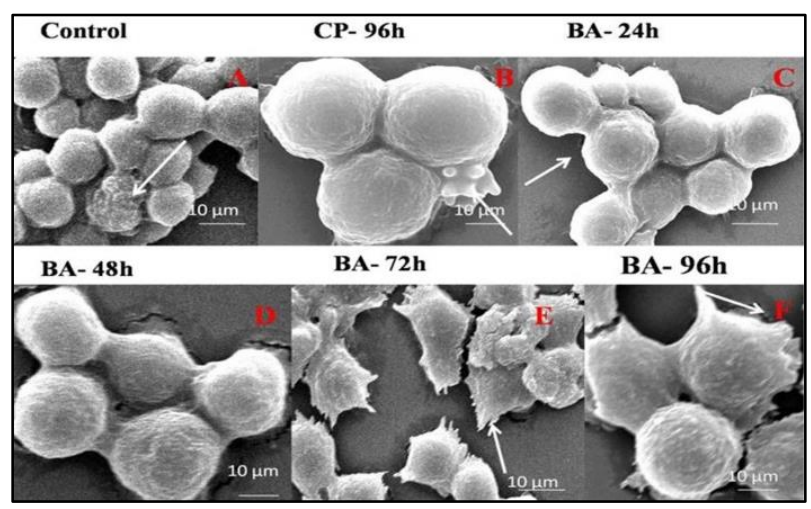

Figure 9: Scanning electron micrograph of DL cells;

(A) control DL cells are round in shape with few membrane projections and ruffles distributed evenly over the cell surface; $(B)$ cisplatin treatment showed apoptotic features including loss in membrane ruffles and appearance of membrane folding/blebbing; (C-F)

betulinic acid treatment for 24-96 hours showed membrane blebbing/ folding and apoptotic bodies. CP: cisplatin; BA: betulinic acid.
To further investigate apoptotic features and the surface morphological changes, DL cells were also processed for SEM. DL cells in control group were round in shape with fine membrane projections and ruffles distributed evenly over the surface. Cisplatin treatment (96 hours) showed membrane folding and shrinkage. At 24 hours of betulinic acid treatment, cells exhibited few membrane projections over the cells surface and a reduction in its length. The surface of DL cells were relatively smooth with no obvious microvilli. Severe cell membranes folding and shrinkage were also evident after 48 hours of treatment. After 72 hours of betulinic acid treatment some irregular blebs and apoptotic bodies were observed and few phagocytic cells were also visible attaching to tumor cells. BA treatment of mice at 96 hours resulted in severe morphological alterations, with a complete loss in fine membrane projections. Cell shrinkage, membrane blebs and severe membrane folding were seen which are typical characteristics features of apoptosis (Figure 9).

\section{Protein estimation}

Proteins are responsible for structure, function and various enzymatic changes in the cell. Protein concentration in DL cells revealed that there is a significant decrease in protein content from 24-96 hours after betulinic acid and cisplatin treatment respectively as compared to that of control (Figure 10).

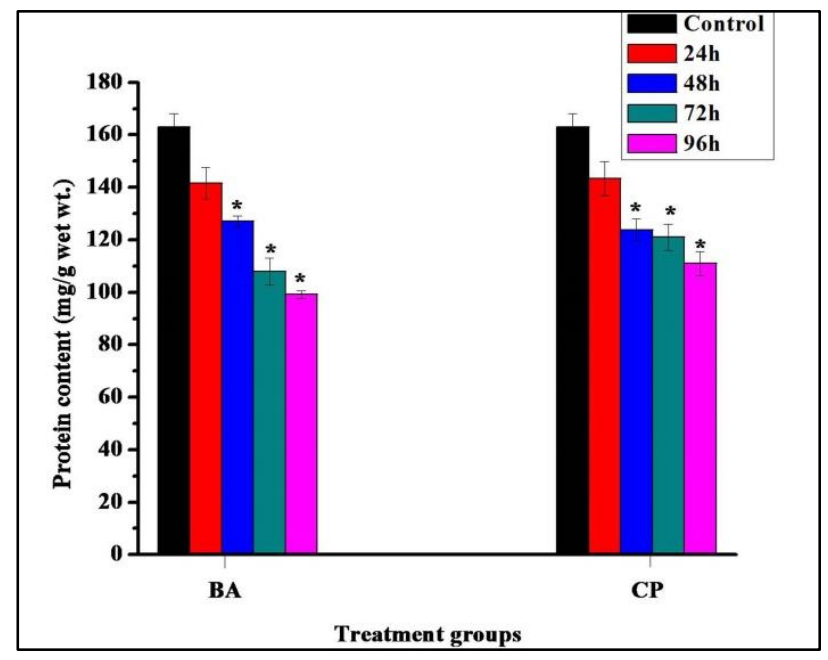

Figure 10: Protein content in DL cells of tumorbearing mice after treatment with betulinic acid and cisplatin respectively. The results are expressed as mean $\pm S D, n=3$. BA- betulinic acid treatment, $C P$ cisplatin treatment.

\section{Total reduced glutathione (GSH)}

GSH is an antioxidant that helps to protect cells against ROS (reactive oxygen species). DL cells showed prominent, time dependent decrease in GSH after BA treatment. In case of reference drug i.e. cisplatin, GSH level also decreased in DL cells (Figure 11). 


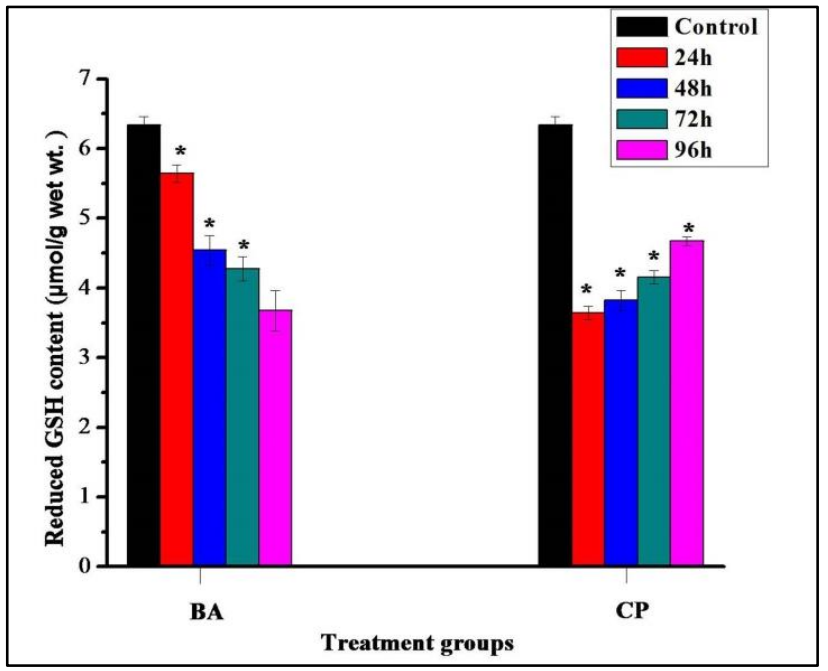

Figure 11: Reduced GSH content in DL cells of tumor-bearing mice after treatment with betulinic acid and cisplatin respectively. The results are expressed as mean \pm SD, $n=3$. BA-betulinic acid treatment, CP- cisplatin treatment.

\section{DISCUSSION}

Although the efficacy of chemotherapy and other standard therapies for different cancer types has been improved during the last decades, the treatment of most human malignancies is still facing high mortality rates. Moreover, toxic side-effects of the chemotherapeutical drugs often limit their full uses. Therefore, the development of novel potent anti-cancer agents is always a primary requirement in cancer research. Since its rediscovery in the 1990s BA has attracted considerable attention as a potential anti-neoplastic drug that lacks toxic effects towards healthy tissues.

In the present study antitumor efficacy of betulinic acid against the ascites Dalton's lymphoma tumor-bearing hosts was evaluated and compared with that of cisplatin as a positive reference drug which is one of the most effective cancer chemotherapeutic agents in clinical practice. To evaluate the antitumor activity of different drugs, ascites Dalton's lymphoma has been commonly used as an important murine experimental tumor model. ${ }^{34}$ The results of the hosts survival data showed that betulinic acid is quite effective against DL, showing a significant increase in life span of the hosts as compared to that of control (Figure 4). The analysis of cell viability of DL cells under different treatment conditions revealed that the number of dead cells was increased significantly in mice after treatment with betulinic acid in a time dependent manner as compared to control (Figure 5 A, B and Figure 6) which may result the increased survivability of the hosts. Further, as compared to DL cells, the spleen cells showed much higher viability at the corresponding time of BA treatment (Figure 6). It signifies that betulinic acid was more cytotoxic to DL cells as compared to normal cells in the host.
Apoptosis was carried out in DL cells using AO/EB method. Apoptosis and/or necrosis are among the key mechanisms by which most compounds exert their cytotoxic effects, especially anticancer agents. Overload of intracellular ROS has been known to induce apoptosis or necrosis or the combination of both. ${ }^{35,36}$ Many of the well-known cytotoxic/anticancer agents belonging to anthracyclins, alkylating agents, epipodophyllotoxins and camptothecins are known to induce apoptosis through oxidative stress-mediated mechanisms. ${ }^{37}$ Apoptosis is a well-described mechanism of cell death induced by a variety of substances. ${ }^{38}$ The assay based on AO/EB staining showed that after betulinic acid treatment DL cells undergo nuclei/ chromatin condensation, and marginalization followed by their fragmentation, cell's shrinkage and membrane blebbing. Finally, the cells produce apoptotic bodies varying in size and structure (Figure 7). The increase in the number of cells stained red with or without fragmented DNA at higher doses of betulinic acid suggests the possibility of late apoptotic cell death. The assay based on AO/EB staining is a good reliable indicator for the authentication of apoptotic features. The results of $\mathrm{AO} / \mathrm{EB}$ showed higher apoptotic index in DL cells in a time dependent manner after treatment with betulinic acid (Figure 8).

To further substantiate the fluorescence based results on betulinic acid-mediated apoptosis, SEM studies were done to observe the morphological characteristics of DL cells. The use of SEM in the analysis of apoptosis is mainly referred to the study of cell surface alterations such as membrane blebbing, shrinking etc. These are important signs of cell injury and may be considered as specific markers of apoptosis. A series of surface changes in DL cells were observed following betulinic acid treatment as observed under a scanning electron microscope. Control DL cells showed evenly distributed membrane projections and ruffles over the cell surface. After 24-96 hours of betulinic acid treatment, cell membrane folding and shrinkage, irregular blebs microvilli, and certain deformities were noted. The formation of membrane blebs/vesicles in tumor cells observed after betulinic acid treatment also support the appearance of apoptotic features (Figure 9).

Protein is an indicator of biological entity or activity. And hence in any biological reaction or estimation or bioprocess, protein analysis and quantification is done to determine the quantity, quality of protein and there by the state of biological reaction or process. In protein estimation a decrease in the protein content was observed in BA treated DL cells as compared to that of control. The protein content in BA treated DL cells was significantly found to decrease from 48-96 hours of treatment as compared to that of control (Figure 10). In cisplatin treatment, protein content was also found to decrease significantly from 48-96 hours as compared to that of control. These changes may involve some alterations in the rate of protein synthesis or decreased uptake of protein in DL cells. 
Glutathione (GSH) is an important antioxidant found widely in plants and animals. Glutathione ( $\gamma$-L-GlutamylL-cysteinyl-glycine) helps to prevent damage to important cellular components caused by reactive oxygen species such as free radicals, peroxides, lipid peroxides and heavy metals. ${ }^{39}$ The role of glutathione (GSH) in cancer has been a matter of interest. Oxidative stress as well as depletion of GSH triggers apoptosis which takes place through mitochondrial intrinsic pathway possibly by inducing loss of mitochondrial transmembrane potential. This event leads to activation of caspase- 3 which plays an important role in carrying out the process of apoptosis. During tumor growth GSH level in DL cells increases. The increase in GSH level in tumor cells could be involved in proliferation and metabolism of tumor cells in the host. Betulinic acid treatment in tumor bearing hosts showed a significant decrease in total GSH levels in DL cells (Figure 11) which may alter the cellular redox balance and facilitate these cells towards the oxidative damage. The decrease in GSH level in DL cells after betulinic acid treatment may be a noteworthy step in the anticancer activity of betulinic acid against Dalton's lymphoma.

\section{CONCLUSION}

In conclusion, it may be suggested that betulinic acid treatment could enhance the therapeutic efficacy by induction of apoptosis in DL cells. Interestingly, betulinic acid has not been reported to develop any side effects in the hosts, thus, it could be a promising potent anti-cancer agent against different types of cancers and Dalton's lymphoma in particular.

\section{ACKNOWLEDGEMENTS}

Authors are grateful to the Head, Department of Zoology, NEHU, Shillong for providing laboratory facilities and to UGC, New Delhi for Non-NET Fellowship to A. Bhaumik.

\section{Funding: No funding sources}

Conflict of interest: None declared

Ethical approval: The study was approved by the Institutional Ethics Committee

\section{REFERENCES}

1. Boyle P, Levin B. World cancer report 2008, WHO, international agency for research on cancer (IARC). Eds; 2008:1-510.

2. Sikora K, Advani S, Koroltchouk V, Magrath I, Levy L, Pinedo H, et al. Essential drugs for cancer therapy: a world health organization consultation. Ann Oncol.1999;10:385-90.

3. Nygren P, Larsson R. Overview of the clinical efficacy of investigational anticancer drug. J Intern Med. 2003;253:46-75.
4. Newman DJ, Cragg GM, Snader KM. Natural products as sources of new drugs over the period 1981-2002. J Nat Prod. 2003;66(7):1022-37.

5. Ogura M, Cordell GA, Farnsworth NR. Constituents of Jacaranda caucana Pittier (Bignoniaceae), Lloydia. Potential anticancer agents. IV. 1977;40:157-68.

6. Sheth K, Jolad S, Wiedhopf R, Cole JR. Tumorinhibitory agent from Hyptis emoryi (Labiatae). J Pharm Sci. 1972;61(11):1819.

7. Miles DH, Kokpol U, Zalkow LH, Steindel SJ, Nabors JB. Preliminary investigation of antitumor activity of Sarracenia flava. J Pharm Sci. 1974;63:613-5.

8. Trumbull ER, Bianchi E, Eckert DJ, Wiedhopf RM, Cole JR. Tumor inhibitory agents from Vauquelinia corymbosa (rosaceae). J Pharm Sci. 1976;65:1407-8.

9. Sandberg F, Duchevska K, Khristov V, Spasov S. Spondianthus preussii var. glaber Engler. Pharmacological screening and occurrence of triterpenes. Acta Pharm Suec. 1987;24:253-6.

10. Singh SS, Patro B, Tripathi V, Srivastava A, Pandey SC, Ghosh AC. J Med Arom Plant Sc. 2002; 24: 1031-7.

11. Tan YM, Yu R, Pezzuto JM. Betulinic acid-induced programmed cell death in human melanoma cells involves mitogen-activated protein kinase activation. Clin Cancer Res. 2003;9:2866-75.

12. Pisha E, Chai H, Lee IS, Chagwedera TE, Farnsworth NR, Cordell AC, et al. Discovery of betulinic acid as a selective inhibitor of human melanoma that functions by induction of apoptosis. Nat Med. 1995;1(10):1046-51.

13. Schuhly W, Heilmann J, Callis I, Sticher O. New triterpenoids with antibacterial activity from Zizyphus joazeiro. Planta Med. 1999;65(8):740-3.

14. Jagadeesh SG, Krupadanam GLD, Srimanna- rayana G, Murthy SS, Kaur A, Raja SS. Tobacco caterpillar antifeedant from the gotti stem wood triter-pene betulinic acid. J Agr Food Chem. 1998;46(7):2797-9.

15. Kashiwada $Y$, Wang HK, Nagao T, Kitanaka S, Yasuda I, Fujioka T, et al. Anti-AIDS agents. 30. Anti-HIV activity of oleanolic acid, pomolic acid, and structurally related triterpenoids. J Nat Prod. 1998;61(9):1090-5.

16. Chang CW, Wu TS, Hsieh YS, Kuo SC, Chao PDL. Terpenoids of Syzygium formosanum. J Nat Prod. 1999;62(2):327-8.

17. Higa M, Ogihara K, Yogi S. Bioactive naphthoquinone derivatives from diospyros maritime blume. Chem Pharm Bull. 1998;46(8):1189-93.

18. Singh P, Sharma S. Triterpenoid constituents of the seed of Diospyros melanoxylon, Tecomella undulata, and Terminalia bellirica. J Indian Chem Soc. 1997;74:504-5.

19. Recio MC, Giner RM, Manez S, Gueho J, Julien HR, Hostettmann K, et al. Investigations on the steroidal anti-inflammatory activity of triterpenoids from Diospyros leucomelas. Planta Med. 1995;61(1):9-12. 
20. Lin HC, Ding HY, Wu YC. Two novel com- pounds from Paeonia suffruticosa. J Nat Prod. 1998;61(3):343-6.

21. Zuco V, Supino R, Righetti SC, Cleris L, Marchesi E, Gambacorti-Passerini C, et al. Selective cytotoxicity of betulinic acid on tumor cell lines, but not on normal cells. Cancer Lett. 2002;175(1):17-25.

22. Pisha E, Chai H, Lee IS, Chagwedera TE, Fransworth NR, Cordell GA, et al. Discovery of betulinic acid as a selective inhibitor of human melanoma that functions by induction of apoptosis. Nat Med. 1995;1:1046-51.

23. Fulda S, Friesen C, Los M, Scaffidi C, Mier W, Benedict $\mathrm{M}$, et al. Betulinic acid triggers CD95 (Apol/Fas)- and p53-independent apoptosis via activation of caspases in neuroectodermal tumors. Cancer Res. 1997;57:4956-64.

24. Fulda S, Scaffidi C, Susin SA, Krammer PH, Kroemer G, Peter ME, et al. Activation of mitochondria and release of mitochondrial apoptogenic factors by betulinic acid. J Biol Chem. 1998;273:33942-8.

25. Fulda S, Jeremias I, Steiner HH, Pietsch T, Debatin KM. Betulinic acid: a new cytotoxic agent against malignant brain-tumor cells. Int $\mathrm{J}$ Cancer. 1999;82:435-41.

26. Schmidt ML, Kuzmanoff KL, Ling-Indeck L, Pezzuto JM. Betulinic acid induces apoptosis in human neuroblastoma cell lines. Eur J Cancer. 1997;33:2007-10.

27. Fulda S, Friesen C, Los M, Scaffidi C, Mier W, Benedict $\mathrm{M}$, et al. Betulinic acid triggers CD95 (APO-1/Fas)- and p53-independent apoptosis via activation of caspases in neuroectodermal tumors. Cancer Res. 1997;57(21):4956-64.

28. Verma AK, Prasad SB. Changes in glutathione, oxidative stress and mitochondrial membrane potential in apoptosis involving the anticancer activity of cantharidin isolated from redheaded blister beetles, Epicauta hirticornis. Anticancer Agents Med Chem. 2013;13:1096-114.
29. Alitheen NB, Mashitoh AR, Yeap SK, Shuhaimi M, Abdul Manaf A, Nordin L. Cytotoxic effect of damnacanthal, nordamnacanthal, zerumbone and betulinic acid isolated from Malaysian plant sources. Int Food Res J. 2010;17:711-9.

30. Talwar GP. Handbook of Practical Immunology. National Book Trust, New Delhi; 1974:329.

31. Shylesh BS, Nair SA, Subramoniam A. Induction of cell specific apoptosis and protection from Dalton's lymphoma challenge in mice by an active fraction from Emilia Sonchifolia. Indian J Pharmacol. 2005;37:232-7.

32. Bradford MM. A rapid and sensitive method for the quantitation of microgram quantities of protein utilizing the principle of protein-dye binding. Anal Biochem. 1976;72:248-54.

33. Sedlak J, Lindsay RH. Estimation of total proteinbound and non-protein sulfhydryl groups in tissue with Ellman's reagent. Anal Biochem. 1968;25:192205.

34. Sriram MI, Mani Kanth SB, Kalishwaralal K, Gurunathan S. Antitumor activity of silver nanoparticles in Dalton's lymphoma ascites tumor model. Int J Nanomed. 2010:753-62.

35. Higuchi Y. Chromosomal DNA fragmentation in apoptosis and necrosis induced by oxidative stress. Biochem Pharmacol. 2003;66(8):1527-35.

36. Pelicano H, Carney D, Huang P. ROS stress in cancer cells and therapeutic implications. Drug Resist Updat. 2004;7(2):97-110.

37. Gerster H. $\beta$-Carotene, vitamin $E$ and vitamin $C$ in different stages of experimental carcinogenesis. Eur $\mathbf{J}$ Clin Nutr. 1995;49(3):155-68.

38. Kroemer G, Reed JC. Mitochondrial control of cell death. Nat Med. 2000;6:513-9.

39. Dash SK, Chattopadhyay S, Ghosh T, Tripathy S, Das S, Das D, et al. Antileukemic efficacy of monomeric manganese-based metal complex on KG1A and K562 cell lines. ISRN Oncol. 2013;1-10.

Cite this article as: Bhaumik A, Prasad SB. Studies on the antitumor potentials of betulinic acid against murine ascites Dalton's lymphoma. Int J Basic Clin Pharmacol 2016;5:1664-71. 